\title{
Between Courts: Female Masquers and Anglo-Spanish Diplomacy, 1603-5
}

The peace signed in London and ratified in Valladolid, bringing to a conclusion twenty years of war between England and Spain, began and ended with a court masque. The negotiations were protracted. James I acceded to the throne in March 1603, but plague delayed his formal entry into London; when the Spanish ambassador sent by Philip III to congratulate his brother monarch arrived at the end of August, he was forced to pursue his quarry across the country, eventually being granted an audience at Winchester in the autumn. Formal talks commenced in 1604, and following the constable of Castile's arrival in May a conference at Somerset House was held in August. The peace was then ratified in the Spanish king's presence the following year, when the lord admiral, Charles Howard, first earl of Nottingham, led an embassy to Philip's corte at Valladolid. These extended diplomatic missions included a succession of entertainments designed as integral features of the peace process. In this essay we focus on the two masques which 'framed' the peacemaking, the first staged at Hampton Court, the second at a specially designed banqueting house newly erected in Valladolid. Women played a conspicuously prominent part in each and, as ostentatiously political events choreographed especially for the occasion, the masques fulfilled important functions, a fact which in part was made possible by court-to-court textual transmission.

Making peace with Spain was James's first major act following his accession, and it would have far-reaching consequences, both at home and abroad. The events of 1603-5 were charged with political and religious tensions that would overshadow not only James's reign but that of his son, Charles I. Indeed, we might regard the half century following the defeat of the Armada as the playing out of an international, triangular relationship between England, Spain, and France, all of which would become embroiled in wars following the death of James, whose aim upon being crowned king of England was to 
bring lasting peace to Europe. The Franco-Hispanic rivalry that would see Charles marry not the Spanish infanta, as his father had hoped, but Henrietta Maria of France, resurfaced in the last years of James's reign, yet it was prominent at its outset, too. France had no desire to see the enmity of its two great European rivals brought to an end, and Henri IV's ambassador correspondingly sought to undermine his Spanish counterpart and frustrate the plans for peace. The early stages of the negotiations took place against a background of political manoeuvring at court, a phenomenon familiar to historians of early modern diplomacy and scholars of the masque.

Although for many protestants it would be James's long-term policy towards Spain that caused anxiety, upon the news of his accession it was his Catholic queen, Anna of Denmark, whose influence was most feared. In light of the role she would play in the peace, these fears were justified. Anna's importance for the masque genre is well established. ${ }^{1}$ Through the court masque, the queen secured for herself a specific role and by extension an important political space for the ladies of the court. Events of early 1604 demonstrate this agency on the queen's part in spectacular fashion. As we show in what follows, not only did the performance of the 'Queen's Masque' (as contemporaries called it) signal, publically and unambiguously, Anna's and James's determination to secure the peace, as the orchestrated humiliation of the French ambassador made clear, but the Spanish ambassador's conveyance of a text of the masque to King Philip underscored its importance.

\section{The Hampton Court Masque}

The English masque with which we are concerned is the earliest (surviving) example of the Stuart reign. ${ }^{2}$ Samuel Daniel's The Vision of the Twelve Goddesses was originally scheduled for Twelfth Night 1604, but was put back two days due to a dispute between the Spanish and French ambassadors. It now transpires, following the discovery of a dispatch that Juan de Tassis, conde de Villamediana, sent to Philip III on 20 January 1604, that Anna intervened specifically to ensure that the Spaniard would be there. ${ }^{3}$ The significance of this intervention would be far-reaching, marking the beginning proper of the treaty negotiations, Anna's role in the peace, and that of her court ladies, as Villamediana's subsequent actions would demonstrate.

Two masques were planned for the court's entertainment. Dudley Carleton watched the tussle between Villamediana and his counterpart, Christophe de Harlay, comte de Beaumont, with amusement, but he was fully aware of the 
politics involved. ${ }^{4}$ As the habitual disputes over precedence implied, it was understood that the ambassadors could not attend both masques, since neither would give way to the other: so, each would be invited to one only. ${ }^{5}$ Yet this strategy failed, at least initially, when Beaumont learned that his invitation was to the Gentlemen's Masque on 1 January, sponsored by the duke of Lennox, while Villamediana would go to the Queen's Masque, scheduled for Twelfth Night. The slight was unambiguous: the Frenchman rejected the invitation to the men's masque, and complained in vain to an exasperated James. Villamediana's letter to Philip, which we discuss elsewhere, makes clear how Anna and James favoured him, Beaumont being forcibly carried into the chamber by Lennox and others to watch the Gentlemen's Masque, a ruse which would thus exclude him from attending the queen's. ${ }^{6}$ The resulting furore led to the performance of The Vision of the Twelve Goddesses being delayed until 8 January.

Samuel Daniel had been recommended to the queen by Lucy, countess of Bedford, who, along with Anna, participated in the masque. Drawing on classical mythology, the masque presented as its centrepiece Anna and eleven court ladies processing as goddesses, three by three, from a 'mountain', positioned at one end of the hall, prior to which the audience was invited to fancy themselves to be asleep, and hence dreaming the 'vision' of which the performance consisted. ' Framed by the figures of Sleep and Night, and accompanied by Iris, messenger of the goddesses, the twelve ladies variously costumed and bearing gifts were successively introduced in verse by the Sybilla, the whole to the singing of the three Graces. Following their descent the goddesses placed their gifts on an altar at the temple, located at the other end of the space. The masque then continued with first the masquers, and then the lords they invited to join them, dancing, Iris drawing the proceedings to a close and the goddesses ascending once more to the mountain. The masque over, the evening concluded, as was customary, with a banquet.

For a writer with strong protestant credentials it was perhaps a curious commission; but Daniel needed to secure patronage, having failed to impress the king on his journey south from Scotland. Thus on the one hand The Vision of the Twelve Goddesses has been read as offering a subtle protestant critique of the new policy, attention being drawn to the prominence of martial power as represented by Pallas and Tethys, for example, and on the other as meekly flattering the new consort. ${ }^{8}$ No doubt, in the complex environment that was the new court, with the peace negotiations delicately poised — and by no means endorsed by all those present — the masque was experienced 
in a variety of ways. As one of the Catholics in the audience, Villamediana may well have been drawn to the theological symbolism of the figure 'three', each group of goddesses suggesting the Trinity; indeed, Venus's costume, 'a mantle of dove-colour', signified in Catholic eyes the Holy Spirit. ${ }^{9}$ Yet in his dedication to the countess of Bedford that prefaced the (authorized) printed edition, Daniel is at pains to make clear that 'though these images have oftentimes divers significations, ... we took them only to serve as hieroglyphics for our present intention. ${ }^{10}$ This remark smacks of authorial sensitivity, but in the light of the purpose of the occasion it may be appropriate to take it at face value. However individual spectators decoded the masque, there is really no need to ponder too deeply the allegorical significance of the goddesses. Anna's role in delaying the masque so the Spanish ambassador was presented to the court as effectively the guest of honour meant that the politics of the occasion overdetermined the content of the masque. To all present, the meaning of the evening was clear.

Daniel complained of 'an indiscreet printer, who without warrant hath divulged the late show at court', an allusion to the 'pirate' text that was shortly in circulation; but it would appear that Daniel himself helped disseminate the text in a rather different direction. ${ }^{11}$ Ambassadors routinely reported on entertainments at court; in several cases these reports have survived. ${ }^{12}$ But the present instance of a text being composed specially and set out formally as a text, rather than as a prose narrative, is (as far as we know) unprecedented. This document is not only of literary value, however, but is important for what its existence as a text may tell us about the circumstances of its production, and hence its political purpose. First, the text Philip received is not the ambassador's eye-witness account written up independently of other agents, but is closely related textually to both the (illicitly) printed masque and Daniel's prefatory dedication. ${ }^{13}$ Second, we may therefore conclude, Daniel was involved in its production. There can be no other plausible explanation for the correspondences between the three texts. And third, it surely follows that Daniel was almost certainly not acting on his own initiative in aiding Villamediana in his textual reconstruction of the masque. The Spanish ambassador had insufficient English, relying on his cousin to act as his translator at court, and would have required both access to Daniel's material and help in translating it. It may well be, then, given her involvement at the outset, that Lucy, countess of Bedford, who spoke Spanish fluently, facilitated both the compiling of the text and Daniel's involvement: indeed, we might even suppose that she had a hand in the translation. ${ }^{14}$ But if the countess is an 
attractive candidate for this role, it seems inconceivable that the queen herself was unaware of the enterprise and very possible that she herself intended that the 'Queen's Masque', and what it stood for, would find its way to Philip.

What struck members of the Hampton Court audience most, unsurprisingly, was the vision of female performance. Carleton remarks on how Anna's dress revealed her legs, and like the anonymous annotator (probably Lord Worcester) of the unauthorized text in circulation by early February, Villamediana took careful note of the ladies' names, which neither printed text provides. ${ }^{15}$ For the Spaniard, lacking English, the experience was primarily a visual one augmented by song (the Spanish version omits entirely the spoken text), but this is consonant with Daniel's conception of the masque form as an emblem, and this example in particular as 'essentially processional and emblematical in structure. ${ }^{16}$ For all concerned the primary impact was the goddesses, descending in order, as Villamediana records: first Pallas (Queen Anna), flanked by Juno (the countess of Suffolk) and Venus (Madame Rich); then Vesta (the countess of Hertford), Diana (the countess of Bedford), and Prosperine (the countess of Derby); next Macaria (Lady Hatton), Concordia (the countess of Nottingham), and Astraea (Lady Walsingham); and finally Flora (Lady Vere), Ceres (Lady Hastings), and Tethys (Lady Hazard). The ambassador's purpose in identifying the ladies becomes clear, moreover, when we examine the diplomatic context more closely. The constable of Castile later noted that Villamediana was especially lavish with his distribution of gifts to English courtiers; it is therefore significant that among the recipients of this largesse were no fewer than six of the 'goddesses': the countesses of Suffolk, Bedford, Hertford, and Derby, and Ladies Rich and Vere. ${ }^{17}$ The constable was apparently surprised that women were to be given gifts at all, ${ }^{18}$ but Villamediana clearly recognized their potential usefulness to Spain, not least because of their proximity to the queen. The countesses of Suffolk and Bedford both held posts in the privy chamber, and indeed the former, in receipt of a generous pension of 4,000 ducats in addition to jewels and monies to the tune of $£ 6,000$, would act as a 'go-between with successive Spanish ambassadors.' ${ }^{19}$ According to Albert Loomie, Villamediana believed her to be secretly a Catholic, ${ }^{20}$ perhaps in part on the grounds of having married into England's most prominent Roman Catholic family; but her worth to Spain resided primarily in her political connection to Robert Cecil, first earl of Salisbury. ${ }^{21}$

The episode might be aligned with Sophie Tomlinson's notion of a shift in scholarship from the (male) authority of printed scripts to the 'political and 
performance texts constituted by the female body in space. ${ }^{22}$ Worcester's jibe about Anna establishing a 'female commonwealth' need not be taken as evidence of an implicit challenge to James's authority, but rather as an indication of an important and specifically female intervention in the peacemaking. ${ }^{23}$ Yet the significance of the 'Queen's Masque' was not restricted to the role it played in England. The compiling of a text and its dispatch by Villamediana to Philip was one of many communications between the courts during the course of the negotiations, but significantly it gave the text an afterlife in Spain, and provided the Habsburg monarch with an opportunity to conclude the 'second leg' of the peace with a nod to what had taken place at Hampton Court and, implicitly, to the role women had played.

\section{Symmetry and Reciprocity}

A notable feature in the negotiations was the importance given to reciprocity. Diplomatic ceremonial was not mere decoration or courtesy, of course, but the performance of status recognition. ${ }^{24}$ The reception accorded the Spanish embassy in England established a precedent for how Nottingham's party expected to be treated in Spain. ${ }^{25}$ For both parties a protocol of reciprocity was calculated to the smallest degree. This ranged from the order of peace, as it were, when the respective negotiators met, to the presentation of gifts, a traditionally important convention which, as Daniel's masque symbolized, featured prominently in the courtly performance of peace, Spanish gifts to the English being reciprocated by Nottingham. ${ }^{26}$ In one respect of course the Spaniards had the advantage, since they could calibrate their 'response' accordingly; but equally, on Spanish soil, English gift-giving operated both as the obligation Philip's gifts in England had engendered and as reciprocation.

Such 'symmetrical expectation' was not without its problems. The 'grammar' or lingua franca of international diplomacy did not erase local variations. When he landed in Spain Nottingham sent a series of demands regarding how he expected to be treated, but many of these were denied him, partly on the grounds that in Spain things were done differently. ${ }^{27}$ Where James had been happy to dine with the constable of Castile, for example, Philip always dined alone, and he refused to acknowledge reciprocity in this case. For their part Spanish counsellors were concerned that they should reciprocate precisely what their own ambassadors had experienced in England - and no more. Inevitably this created a number of culturally sensitive problems. ${ }^{28}$ 
Mutual expectation of reciprocity produced a high degree of symmetry. This, we propose, in part explains both the design and placing of the Spanish masque. What seems clear is that the transmission of a text of The Vision of the Twelve Goddesses to Philip resulted in a carefully choreographed act of reciprocation in Valladolid. The masque that Anna used to signal her promotion of the peace was echoed, eighteen months later, in the device with which Philip formally concluded the English embassy's mission.

\section{Court Entertainment in Spain}

Philip III famously enjoyed plays and court entertainments; his reputation is of a careless ruler who left affairs of state to his valido, or favourite, the duke of Lerma, and that of his monarchy is one of fabulous feasts and endless celebrations invariably accompanied by plays and masques. In his correspondence with his daughter Ana, the infant protagonist of the masque in Valladolid and later queen consort to Louis XIII of France, he frequently included news of the latest comedies at court, sometimes accompanied by relaciones (accounts) of the events or even the texts of the performances themselves. ${ }^{29}$ Undoubtedly, when Philip received Villamediana's communication he read it with particular interest, not only for the signal it sent regarding the peace, but also because the Relation of the Masque Presented Before the King of England by the Queen was a reliable source of information about the tastes and practices at the English court. ${ }^{30}$

Masques had been a common practice in the Spanish royal household for fifty years; and although the genre shared a common court language across Europe, each country developed its own tradition. Philip II had been lavishly entertained in the Low Countries when he was prince and in England as king consort, ${ }^{31}$ but it seems that back in Spain he was less of an enthusiast for theatre and spectacle than his son would be. As with James I in England, masquing was promoted by the ladies of Philip's court. Isabel of Valois, Philip's third wife, and his widowed sister Princess Juana of Portugal, sometimes engaged in theatrical competitions: in 1564, they proposed a wager to see which of them could present, with their ladies, the most spectacular masque in a series of variously decorated chambers. ${ }^{32} \mathrm{~A}$ year later the princess's ladies organized a 'farce' attended by the king, but he was not favourably impressed. In recompense the queen's ladies arranged another that apparently pleased all present. ${ }^{33}$ These two women were also enthusiastic sponsors of playing companies (between 1561 and 1568, forty-one plays were performed at court), 
and though court performance fell off after the death of Isabel of Valois, the arrival of the widowed Empress Maria (spouse of Maximilian II) in 1581 revived the tradition. She it was who arranged for the mythological tragicomedy Fábula de Dafne to be performed by court ladies in the chambers of the king's daughter, Infanta Isabel Clara Eugenia, a performance also attended by her brother and future king, Prince Philip. ${ }^{34}$

With the accession of Philip III in 1598 the monarch himself chose to become directly involved in performances. The celebration of his wedding to Margarita of Austria in Valencia was the occasion of several plays, tournaments, and balls, some of them staged in the village of Denia, the seat of the duke of Lerma. The middle of one such play was interrupted by a captain who announced that several galleys of moors had been sighted off the coast. The next day, as the king and his retinue travelled along the coast, 100 knights tricked out as moors ambushed them, 'and there were ladies who fainted believing it was all true'. ${ }^{35}$ The celebrations continued for several months as the newlywed couple visited cities across Spain. There was, then, an established masquing tradition, prior to the English embassy's arrival in 1605 , and Villamediana's text was received, read, and acted on in this cultural context.

\section{The Salón de Saraos in Valladolid}

Three years after his accession Philip III moved the court from Madrid to Valladolid, for reasons still debated by historians, as they were by contemporaries. The decision involved the relocation of the entire administration together with the nobles, clergy, secretaries, and artists attendant on the court. The only apparent winner in all of this was the duke of Lerma, who had bought property in the centre of the city that he later would resell for a considerable profit. ${ }^{36}$ The change was even more inconvenient if we consider that there was no royal palace as such in Valladolid, so the court was established in one of the palaces the duke had purchased only the year before, and work had to be undertaken to adapt it to its new function. In the event, the king returned permanently to Madrid only five years later. But for a short time, at an important moment in Spain's history, the court was based at Valladolid.

One of the features the new administrative buildings lacked was an appropriate ceremonial hall to serve as a space for courtly entertainments. The Alcazar in Madrid had such a room in what was known originally as the 
hall of the empress and later as the salón de comedias, so a salón de saraos in Valladolid was designed along similar lines. ${ }^{37}$ Its construction did not begin until August 1604, however, exactly when the peace was being signed in London, a circumstance that was probably not entirely coincidental. A hanging passageway was erected connecting the royal palace with the houses of the count of Miranda (across the street from the palace) which the king had bought to extend his property. The passageway signaled the beginning of the project but the major work was not undertaken until January 1605. The official reason for the salon was the imminent birth of a royal baby. ${ }^{38}$ This would be the third royal arrival after the Infanta Ana (1601) and the Infanta María (1603), the latter dying shortly after birth. As it happened a healthy male baby was born in mid-April; but since the new building would not be finished for another month and a half, the christening was postponed until 29 May. Pinheiro da Veiga, a Portuguese traveler in Valladolid, remarks that the king ordered the postponement of the christening until after Nottingham's arrival. ${ }^{39}$

News then reached the court that the English had weighed anchor off La Coruña. This was unfortunate, for Philip had made arrangements for them to travel from Santander to Valladolid, fitting out lodgings en route to ensure a comfortable journey for the ambassador and his train, but due to confusion and poor weather, they had landed in the wrong place. The journey from $\mathrm{La}$ Coruña was longer and more troublesome, and now arrangements had to be improvised. Philip instructed Nottingham to remain in Galicia for a month before order was given that he could begin his journey, thus giving time for preparations to be made anew, but also, most probably, for the salón to be completed. What seems clear is that Philip orchestrated events - the christening, the ratification of the peace, and the inauguration of the salón - to coincide. Indeed, one of the English accounts of Nottingham's journey states plainly that the hall was built 'of purpose for my lordes coming. ${ }^{40}$ Happy coincidence these events may have been, but Philip stage-managed the celebrations as a civic and royal performance of the peace.

In five months the hall was ready, to widespread admiration: 'It was done so speedily that the objections raised turned to praise, as the building is among the best in the world ${ }^{41}$ Its dimensions were superior to those of the hall in the Alcazar, some forty-five metres in length, fifteen metres wide, and ten metres high. The height allowed for an elevated gallery surrounding the hall, and three-tiered stands on opposite sides of the space. Access to the stands was through a series of 'secret stairs and numerous doors conveniently 
placed, connecting the stairs to the structure with artful correspondence, as in a sort of theatre. ${ }^{42}$ This comparison has led modern critics to debate to what extent it shared the physical properties of a theatre, but more importantly we should consider that it was designed for a specific performance, with the monarchs as actors and the English as audience. ${ }^{43}$

The decoration of the hall was a mixture of baroque, with a multitude of mirrors and paintings using the trompe-l'œil technique, and classicism, represented by a temple of twelve columns, mythological figures, and a frontispiece covering the thrones. Lucas Marchante observes that 'the design was done in such a way that the architectural and decorative programs displayed in the room would be an essential part of the performative text. ${ }^{44}$ He recognizes in the various elements an intention to convey the imperial power of the Habsburg dynasty. Thus the tapestries hung on the walls representing the conquest of Tunis by Emperor Charles V in 1535 identified the royal members present with their lineage and achievements. Marchante argues that 'the process of surrogation was vital for the survival of the community and, anchored in the iconic memory of Charles V, would pass through the present king Philip III to the newborn heir, the future king Philip IV'. ${ }^{45}$ This dynastic iconography would frame the representation of the masque: the hall, in short, was built to offer the best means of displaying power, wealth, and artistic sophistication, all in honour of the crown.

\section{Performing the Peace}

Thus the hall was not inaugurated, as expected, with the masque celebrating the birth of the prince (who was already two months old), but for the ratification of the peace. During the period the 'English heretics', as they were known, spent in Valladolid prior to this ceremony they had been guests of honour in a city that spent these days celebrating events and organizing processions on every possible occasion. ${ }^{46}$ The English witnessed the christening of the royal prince, the Corpus Christi procession, the procession of the queen attending mass after childbirth, a bull-fight, a tournament, and a military parade. The actual ratification, however, was a comparatively private affair that took place without prior announcement, as one of the English accounts reveals: 47 'the Constable \& Don Pedro de Suniga, being sent to accompany his Lordship thither [to the court] as also divers other Knights and Lords, whose names, for the sodainesse of their coming and the number of them being so many, could not be had ... So the king and his lords went 
together into a very faire banqueting house very latelie built. ${ }^{48}$ The choice of the 'banqueting house', as Robert Treswell calls it, for the oath-taking was controversial because Nottingham had expressly demanded that the oath be taken in a church, and moreover that it should be he who would hold the terms of the treaty in his hands. ${ }^{49}$ In the event none of Nottingham's demands was met, partly on the grounds that in church a mass would have to be heard. It may be that, knowing that a mass would be unacceptable to the lord admiral, Philip used the opportunity to orchestrate the ceremony to his advantage. ${ }^{50}$ Although it took place in a secular space he used symbols of religion as he saw fit, including a crucifix and a missal; the cardinal of Toledo conducted the ceremony, and the throne from which the king presided was magnificent, while Nottingham, humiliatingly, was made to sit on a low stool, 'where, after having rejected it with great courtesy and reverence, he sat down': his only role was to ask the constable of Castile to ask the cardinal to ask the king to sign the agreement. ${ }^{51}$ Nottingham must have felt slighted by this treatment, as is evidenced by the fact that following the ceremony he demanded that preparations be made for his immediate departure. ${ }^{52}$

But Philip could not allow the English ambassador to leave before attending the one event that had concentrated his energies over these past months. Just as a masque had been the unequivocal gesture to open negotiations, another was to provide a coda to the process. Whether the Spanish masque was inspired, aesthetically, by the English masque is hard to ascertain. It is, however, worth noting the correspondences between these events as signs of an intentional reciprocity on the part of the Spanish court. The elaborate 'hostipitality' with which the Spaniards received their English visitors was best illustrated in a performance that mirrored Daniel's masque, while being designed to surpass it in grandeur, splendour, and artifice. ${ }^{53}$

A week after the ratification the sarao took place. Contemporary accounts make clear that it was the most fabulous event of this most eventful of seasons. ${ }^{54}$ At nine o'clock, when all the spectators had managed to gain a seat, a mechanical statue representing Fame, on top of the temple of Virtue, sounded a trumpet to signal the start. A song performed by two choirs of singers located on opposite sides of the hall described how Virtue had descended to Pintia (the Roman name for Valladolid) to offer herself to the newly born Prince Philip. Then, through a door at the far end of the room, entered the masquers: first, thirty musicians playing their instruments, followed by twenty-four pages carrying lanterns, all masked. They were followed by 'six Virgins dauncing: one bearing in her hand a Sunne: another a 
braunch of Olive tree: another an Ancor: another a Sword with two points: on either point a bunch of flowers. ${ }^{55}$ These were the meninas (girls in waiting) as described by Treswell; the Spanish Relacion explains what each represented: Magnanimity carrying the double-edged sword, Liberality with the sun, Security with an anchor, Prudence with a mirror and a triangle signifying time past, present, and future, Hope with a branch of laurel, and Peace with an olive branch. ${ }^{56}$ After the meninas a chariot in the shape of a vessel appeared, pulled by two small horses; on top of the vessel sat the infanta, accompanied by two other little girls and a lady, the duchess of Villahermosa, who represented Happiness with a cornucopia and the Phoenix. The Infanta Ana, who was only four, personified the compound of all other virtues; she wore a golden helmet with diamonds and feathers, and carried a golden sceptre in her hands with a blue bird. The infanta was clearly the focus of this emblematic display, representing the virtues with which her brother was born and the continuity of the Habsburg dynasty secured by the recent birth.

The procession advanced solemnly across the room amid music and lights until it reached the temple at the far end, where the infanta was placed. Then, 'at the neather end of the said hall stood the Maskers in a Gallery contrived for the purpose, who upon the drawing of a Curtyn, appeared as it were in clouds. ${ }^{57}$ These maskers were twenty-eight ladies and gentlemen, dressed as fourteen heroes and fourteen nymphs, who appeared in a chamber full of mirrors that reflected the lights of the candles they were carrying. A song described how they were to descend to earth to assist in the education of the prince, and then in groups of four the heroes and nymphs mounted a mechanical cloud which then lowered them to the ground, where they performed a dance that ended at the temple of Virtue with expressions of reverence to the infanta. The last cloud carried the king and queen, who also danced and then sat on the throne, accompanying their daughter.

The participants then removed their masks, thereby signaling the conclusion of the mascarada; however, the event went on until three in the morning with all kinds of dances. The English caused considerable comment with their gambols and skips, Pinheiro recognizing that they were the better dancers, 'though with less gravity than ours.' ${ }^{58}$ Nottingham was invited to dance by the queen, a gesture that was considered a singular favour: 'this may have compensated for not having invited him to dine at the table with the king, as was done by the English [king] for the Constable. ${ }^{59}$

The echoes between the two masques are evident, and go beyond a shared courtly language. Both masques use the hall as an open space, with a focal 
point represented by a temple and a secondary element from which the performers descend (mountain and cloud respectively). The emblematic nature of the masquers, who parade holding symbolic objects, is key to understanding the conceit of each, while the central role of females (girls in the Spanish case) provides the performance with a complex quality combining the strength of the visual display with the modesty of their position at court. A striking resemblance is in the costumes of Queen Anna and Infanta Ana as they are described in the extant texts: the queen wore 'a helmet of diamonds and in it a plume of white feathers'; the infanta was attired 'with a golden helmet on her head with many diamonds and feathers'. Unfortunately no extant visual document allows for comparison of the costumes, but nor was there one from which the Spanish could take their inspiration, save Villamediana's letter. In other respects, culturally, there are divergences of course. In this Spanish masque there are no actors, since all the text is sung, and the conceit is rather more contrived in Daniel's, with the audience 'asleep' for the 'dream' while the Sybilla has her vision through a prospective mirror.

Most striking of all, however, both as an innovation and for its symbolism, is the role played by the infanta. What could this parading of a royal princess mean? The answer would seem to lie in the occasion, rather than in the scripted masque as such. Like the figures of empire and sea power in Daniel's masque, the banqueting hall tapestries that heralded Habsburg power signified to the other, the guest, the host's power. Despite forging a peace, England and Spain each reminded the other of its martial prowess. But such shows of strength were also a form of dynastic wooing. Just as The Vision of the Twelve Goddesses offered a reminder (to the English and Scots, as well as to Spain's emissary) that this was to be a peace with honour, rather than a capitulation, so the Spanish reception in Valladolid was designed to impress upon the English visitors the wealth and splendour — and power — of the Spanish empire. But with the ratification, the two nations were now properly at peace, and the logical next step was a marital alliance.

Gustav Ungerer has proposed that James and Anna intended to pursue a Spanish match (presumably for Prince Henry) from the earliest months of the reign, and such a plan would certainly have been consonant with longerterm objectives, of which the peace was the crucial, first step. ${ }^{60}$ In the event, it did not materialize until 1623 , and ended in a fiasco, relations deteriorating to the point that war was resumed two years later. ${ }^{61}$ The Infanta Maria, whom Charles pursued then, was not yet born in 1605, but her sister the Infanta Ana, Philip's only daughter at that time, fulfilled a deeply symbolic 
role in the masque designed especially for Nottingham, whose presence at the event Philip insisted on (as Anna of Denmark had with Villamediana). The best explanation for the infanta's presence is simply that Spain, too, had longer-term objectives that the ratified peace now made possible. Thus, while the baptism of the prince (the future Philip IV, who would preside over the Spanish Match affair and lead the country to war against England in 1625) was an important ceremony into which Nottingham (and the peace mission) was co-opted, the sarao celebrated the peace proper by conveying an altogether different message, emphasizing the marital, rather than the martial, as it were.

\section{Notes}

We would like to acknowledge the archivists at the Archivo General de Simancas for their assistance and the Spanish Government for funding our research (Proyecto I+D+i Libros, viajes, fe y diplomacia: interpretación y representación del intercambio cultural entre España e Inglaterra en la Edad Moderna. FF12009-10816).

1 See especially Clare McManus, Women on the Renaissance Stage: Anna of Denmark and Female Masquing in the Stuart Court 1590-1619 (Manchester, 2002), and Sophie Tomlinson, Women on Stage in Stuart Drama (Cambridge, 2005).

2 A masque was performed at Winchester in late 1603, but neither it nor the Gentlemen's Masque of 1 January 1604 is extant.

3 See Berta Cano-Echevarría and Mark Hutchings, 'The Spanish Ambassador and The Vision of the Twelve Goddesses: A New Document', English Literary Renaissance 42.2 (2012), 223-57. In this article we refer to documents held in the Archivo General de Simancas, fo. 147-50, E842. All dates given are English style; continental dating was ten days ahead, so in the Simancas document Villamediana dates his letter 30 January and the masque 18 January. According to Villamediana, the masque was rearranged for 'a time that would be to my liking' (Cano-Echevarría and Hutchings, 'The Spanish Ambassador', 247).

4 See Carleton's letter to John Chamberlain, 15 January 1604, in Maurice Lee, Jr (ed.), Dudley Carleton to John Chamberlain, 1603-1624: Jacobean Letters (New Brunswick, 1972), 55.

5 See William Roosen, 'Early Modern Diplomatic Ceremonial: A Systems Approach', The Journal of Modern History 52.3 (September 1980); for the notoriously fractious relations between Spanish and French ambassadors to England, see 462-3. 
6 See Cano-Echevarría and Hutchings, 'The Spanish Ambassador', 245-6. The French king Henri IV invited both the English and Spanish ambassadors to be present for the performance of Marie de Medici's ballet at court on 24 January 1605, a gesture that was clearly significant for those involved given that the English representative was the duke of Lennox himself. See Melinda J. Gough, 'Marie de Medici's 1605 ballet de la reine: New Evidence and Analysis', Early Theatre 15.1 (2012).

7 For a sketch of the layout of the hall for this masque, see Glynn Wickham, Early English Stages 1300 to 1660: Volume Two: 1576 to 1660, Part 1 (London, 1963), 268-9.

8 For the first of these interpretations, see Peter Holbrook, 'Jacobean Masques and the Jacobean Peace', in David Bevington and Peter Holbrook (eds), The Politics of the Stuart Court Masque (Cambridge, 1998), especially 67-78; for the second, Graham Parry, 'The Politics of the Jacobean Masque', in J.R. Mulryne and Margaret Shewring (eds), Theatre and Government Under the Early Stuarts (Cambridge, 1993), especially $91-2$.

9 All references to Daniel's masque are to Joan Rees's edition in T.J.B. Spencer and Stanley Wells (eds), A Book of Masques in Honour of Allardyce Nicoll (Cambridge, 1967), 27.

10 Ibid, 26.

11 Ibid, 25.

12 See John Orrell, 'The Agent of Savoy at The Somerset Masque', Review of English Studies 28 (1977), 301-5.

13 This relationship between the two printed texts, both published in 1604, and Villamediana's, is considered in detail in Cano-Echevarría and Hutchings, 'The Spanish Ambassador', 233-42.

14 John Florio apparently 'praised her for her ability to understand, read, write, and speak Italian, French, and Spanish'; see Helen Payne, 'Russell, Lucy, countess of Bedford (bap. 1581, d. 1627)', in the online Oxford Dictionary of National Biography (Oxford and New York, 2004-). On knowledge of the Spanish language at the English court, see Hannah Crummé, 'The Impact of Lord Burghley and the Earl of Leicester's Spanish Secretariats', SEDERI 21 (2001), 7-27.

15 This text is in the British Library. Its recording of names and roles is not entirely accurate, however, unlike Villamediana's, for which Daniel's preface, published later, offers corroboration; see Cano-Echevarría and Hutchings, 'The Spanish Ambassador', 238.

16 Geoffrey Creigh, 'Samuel Daniel's Masque The Vision of the Twelve Goddesses', Essays and Studies 24 (1971), 22-35, especially 29. 
17 Gustav Ungerer, 'Juan Pantoja de la Cruz and the Circulation of Gifts between the English and Spanish Courts, 1604/5', SEDERI 9 (1998), 59-78, especially 63.

18 Ibid, 64.

19 Helen Payne, 'Howard, Katherine, countess of Suffolk (b. in or after 1564, d. 1638)', online Oxford Dictionary of National Biography (Oxford and New York, 2004-).

20 Albert J. Loomie, Toleration and Diplomacy: The Religious Issues in Anglo-Spanish Relations, 1603-05 (Philadelphia, 1963), 53; cited in Payne, 'Howard, Katherine, countess of Suffolk'.

21 Payne, 'Howard, Katherine, countess of Suffolk'.

22 Tomlinson, Women on Stage in Stuart Drama, 19.

23 Ernest Law (ed.), 'The Vision of the Twelve Goddesses, a Royall Masque' by Samuel Daniel (London, 1880), 23.

24 See especially Roosen, 'Early Modern Diplomatic Ceremonial'.

25 For a brief but informative account of the receptions given to each embassy, see Janette Dillon, The Language of Space in Court Performance, 1400-1625 (Cambridge, 2010), 83-90.

26 The sociological significance of gift-giving has long been recognized. See for example Felicity Heal, Hospitality in Early Modern England (Oxford, 1990) and Alison V. Scott, Selfish Gifts: The Politics of Exchange and English Courtly Literature 15801628 (Madison, 2006). For the details of the gifts and their recipients, see Ungerer, 'Juan Pantoja de la Cruz'.

27 The document, together with Philip's annotations, in his hand, is in the Archivo General de Simancas, Estado 2557, fol. 37.

28 The nature of these difficulties is rather ill-concealed in Spanish accounts; the English texts are more circumspect and provide little sense of tensions surrounding Nottingham's reception.

29 Teresa Ferrer Valls, La práctica escénica cortesana: De la epoca del emperador a la de Felipe III (London, 1991), 121.

30 Relacion de la mascara, representada delante del rey de Ynglaterra por la reyna en 18 de enero 1604, Archivo de Simancas, Estado 842, Folio 148-50. For a transcription and translation of this text, together with Villamediana's accompanying letter, see Cano-Echevarría and Hutchings, 'The Spanish Ambassador', 245-57.

31 See Juan Calvete de Estrella, El felicissimo viaie d'el principe don Phelippe, hijo d'el emperador don Carlos Quinto Maximo, desde España à Alemaña (Antwerp, 1552) and Alexander Samson, 'Changing places: the marriage and royal entry of Philip, prince of Austria and Mary Tudor, July-August 1554', The Sixteenth Century Journal (2005), 761-84. 
32 'Relación de las máscaras celebradas en el Alcazar de Madrid el 5 de enero de 1564, dia de reyes', in Teresa Ferrer Valls (ed.), Nobleza y espectáculo teatral (1535-1622): Estudio y documentos (Sevilla, 1993), 183-91.

33 Ferrer Valls, La práctica escénica cortesana, 68-9.

34 Ibid, 70, 144-7.

35 'y no faltó damas a quien pensando era de veras se les quitó el color'. Ferrer Valls, Nobleza y espectáculo teatral, 208. All translations from Spanish sources are by the authors.

36 On the reasons for moving the court in 1601, see F.C. Sainz de Robles, Por qué es Madrid capital de España (Madrid, 1987) and Javier Perez Gil, El palacio real de Valladolid, sede de la corte de Felipe III (1601-1606), 173-201.

37 Jose Manuel Barbeito, El Alcázar de Madrid (Madrid, 1992), 128-31. The word sarao is an old-fashioned Spanish term denoting a social event or celebration involving music, dance, and entertainment.

38 Luis Cabrera de Cordoba, Relaciones de las cosas sucedidas en la corte de España desde 1599 hasta 1614 (Madrid, 1857), 238.

39 Tomé Pinheiro da Veiga, Fastiginia: Vida cotidiana en la corte de Valladolid (Valladolid, 1969), 64.

40 The Royal Entertainment of the Right Honourable the Earle of Nottingham (Edinburgh 1605), 15.

41 'Se hizo con tanta brevedad, que las objecciones que a esto se ponian, se convirtieron en alabanças, pues la fabrica ha sido de las mejores del mundo'; Relacion de lo sucedido en la ciudad de Valladolid, desde el punto del felicissimo nacimiento del Principe Don Felipe (Valladolid, 1605), 39.

42 'con escaleras secretas, y muchas puertas en convinientes lugares, por donde con la escalera se comunica la fabrica con artificiosa correspondencia, demanera que viene a ser a modo de teatro'. Ibid, 40.

43 Javier Pérez Gil argues that it is a new type of structure, quite different from a conventional theatre, conceived for royal ceremonies, processions, and dances. Pérez Gil, El palacio real de Valladolid, 444. Conversely, Teresa Ferrer Valls regards it more conventionally as a private theatre. See her 'Teatros cortesanos anteriores a la construccion del Coliseo del Buen Retiro', Homenatge a Amelia Garcia-Valdecasas Jimenez (Valencia, 1995), 355-71.

44 Lucas Marchante-Aragón, 'Temples of Dynastic Memory in the Seventeenth Century: Valladolid and London', Viator: Medieval and Renaissance Studies 36 (2005), 606.

45 Ibid, 613.

46 As described in Pinheiro da Veiga, Fastiginia, 79-160. 
47 The oath took place on 8 June in the evening of Corpus Christi (according to the Spanish calendar).

48 Robert Treswell, A Relation of Such Things as Were Observed to Happen in the Journey of the Right Honourable Charles Earle of Nottingham (London 1605), 44.

49 Archivo General de Simancas, Estado 2557, fol. 37. These discussions were recorded on 3 June so the decisions concerning the ceremony were taken in some haste. The king had decided previously, however, that the new hall was going to be the setting (one of the points in this consulta refers to his previous resolution to this effect).

50 In London the constable of Castile had been concealed by a curtain, thus 'protecting' him from the protestant symbols in the church. Nottingham desired reciprocal treatment, but documents in the Simancas archive (Estado 2557, Folio 37) indicate Philip's insistence that the banqueting hall would be the venue for the ratification.

51 'el cual despues de haberlo rehusado con mucho comedimiento y reverencias se sentó [...] y el Almirante se acercó al Condestable y le pidio que S.M. firmase aquel papel, el cual se lo dijo al Cardenal y él al Rey'; Cabrera de Cordoba, Relaciones de las cosas sucedidas, 248-9.

52 Relacion de lo sucedido, 31.

53 For this concept, see Jacques Derrida, 'Hostipitality', Angelaki: Journal of the Theoretical Humanities 5.3 (2000), 3-18.

54 Apart from the birth of the prince and the ratification of the peace, during the three-month period from April to June 1605, the death and election of two popes, Easter, Corpus Christi, the king's birthday, and the christening of the prince were all commemorated with various processions, street decorations, and public and private entertainments.

55 Treswell, A Relation of Such Things, 51.

56 Relacion de lo Sucedido, 41-2.

57 Treswell, A Relation of Such Things, 52.

58 Pinheiro da Veiga, Fastiginia, 157.

59 'y pudo suplir esto no haberle dado su mesa el Rey, como se la dio el de Inglaterra al Condestable'; Cabrera de Cordoba, Relaciones de las cosas sucedidas, 252.

60 Ungerer, 'Juan Pantoja de la Cruz', 62.

61 See Glyn Redworth, The Prince and the Infanta: the Cultural Poetics of the Spanish Match (Yale, 2003). 